\title{
Positive Photocatalysis of a Diels-Alder Reaction by Quenching of Excited Naphthalene-Indole Charge Transfer Complex with Cyclohexadiene
}

\author{
María González-Béjar, ${ }^{a}$ Salah-Eddine Stiriba, ${ }^{a}$ Miguel A. Miranda, \\ Julia Pérez-Prieto ${ }^{\mathrm{a}^{*}}$ \\ ${ }^{a}$ Departamento de Química Orgánica/Instituto de Ciencia Molecular, \\ Universidad de Valencia, Polígono La Coma, 46980, Paterna, Valencia, \\ Spain and ${ }^{b}$ Departamento de Química/Instituto de Tecnología Química \\ UPV-CSIC, Universidad Politécnica de Valencia, Camino de Vera s/n, \\ 46022, Valencia, Spain. \\ E-mail :julia.perez@uv.es
}

\section{Supporting Information}

Org. Lett.

SI 2: Experimental procedure and data of the known compounds 1 with a yield reported.

SI 3: Figure S1: ${ }^{1} \mathrm{H}-\mathrm{NMR}$ spectrum of the reaction crude used for the analysis of the stereochemical composition.

SI 4: Figure S2: GC trace of Diels-Alder reaction crude.

SI 5: Figure S3: ${ }^{1} \mathrm{H}-\mathrm{NMR}$ spectrum of one of the fractions collected during the separation of endo- and exo-1.

SI 6: Figure S4: ${ }^{1} \mathrm{H}-\mathrm{NMR}$ spectrum of endo-1.

SI 7: Figure S5: GC/MS spectrum of endo-1.

SI 8: Figure S6: ${ }^{1} \mathrm{H}-\mathrm{NMR}$ spectrum of exo- $\mathbf{1}$.

SI 9: Figure S7: GC/MS spectrum of exo-1. 
Standard Procedure for the Diels-Alder Reactions: To a deaerated freshly distilled dichloromethane solution of $\mathrm{InH}(0.5 \mathrm{mmol}), \mathrm{CHD}(1.0 \mathrm{mmol})$, powdered $\mathrm{NaHCO}_{3}(1.0$ $\mathrm{mmol})$ and acetyl chloride $(0.5 \mathrm{mmol})$, NP $(0.025 \mathrm{mmol})$ was added under nitrogen atmosphere. After irradiation, water was added and the organic phase was separated and dried over $\mathrm{Na}_{2} \mathrm{SO}_{4}$. Column chromatography was performed on silica gel 60 mesh (0.040-0.063 mm) using hexane:ethyl acetate, (7:1) as eluent. A mixture of endo and exo-1 was obtained (47.4 mg, $0.2 \mathrm{mmol}, 40 \%$ ). Separation of diastereoisomers was accomplished by HPLC using a LiChrospher ${ }^{\circledR}$ Si60 $(10 \mu \mathrm{m})$ silica column and hexane/ethyl acetate mixtures as eluents (UV detection at $\lambda=300 \mathrm{~nm}$ ). ${ }^{1} \mathrm{H}-\mathrm{NMR}$ spectra were recorded in a $300 \mathrm{MHz}$ spectrometer; chemical shifts $(\delta)$ are reported in ppm relative to TMS. GC/MS analysis were made on a low resolution quadrupole mass selective detector connected to a gas chromatography equipped with DB-5 capillary column (30 m x $0.32 \mathrm{~mm}$ i.d.; film thickness $0.25 \mu \mathrm{m})$. GC/MS data were taken under electron ionization (EI).

Fluorescence spectroscopy. Steady-state fluorescence spectra were measured on a Photon Technology spectrofluorometer, equipped with a lamp power supply (LPS220B), working at room temperature. Quantum yield measurements were measured and compared to quinine sulfate (dissolved in $0.5 \mathrm{M}$ sulfuric acid). For relative emission quantum yield measurement, the excitation bandwidth was $1 \mathrm{~nm}$, and the absorbance of the measured sample and the quinine sulfate were fixed at absorbance ca. $0.3(\lambda=310$ $\mathrm{nm})$. Samples were placed into quartz cells of $1 \mathrm{~cm}$ path length and purged with nitrogen for $20 \mathrm{~min}$. Fluorescence decays were recorded on the same spectrofluorometer using a Time Master control module lamp.

Data of the known reportedly compounds endo- and exo- $N$ - Acetyl- 1,4,4a,9atetrahydro- 1,4-ethanocarbazole (1):

endo-1: ${ }^{1} \mathrm{H}$ NMR (300 MHz, $\left.\mathrm{CDCl}_{3}\right): \delta 1.2-1.7(\mathrm{~m}, 4 \mathrm{H}), 2.2$ and $2.3(2 \mathrm{~s}, 3 \mathrm{H}), 2.8$ and $2.9(2 \mathrm{bb}, 1 \mathrm{H}), 3.0$ and $3.3(2 \mathrm{bb}, 1 \mathrm{H}), 3.4$ and $3.6\left(\mathrm{~d}, J_{1}=8.4 \mathrm{~Hz}\right.$, and dd, $J_{1}=9.3 \mathrm{~Hz}, J_{2}$ $=2.4 \mathrm{~Hz}$, respectively, $1 \mathrm{H}), 4.3$ and $4.6\left(\mathrm{dd}, J_{l}=9.4 \mathrm{~Hz}, J_{2}=2.4 \mathrm{~Hz}\right.$, and dd, $J_{l}=8.1$ $\left.\mathrm{Hz}, J_{2}=2.1 \mathrm{~Hz}, 1 \mathrm{H}\right), 5.8-6.0(\mathrm{~m}, 2 \mathrm{H}), 6.9-7.1(\mathrm{~m}, 3 \mathrm{H}), 7.0$ and $8.0(\mathrm{~d}, J=7.8 \mathrm{~Hz}$, $1 \mathrm{H})$; all signals are doubled due to the presence of two amide rotamers. MS: $m / z(\%): 239$ $\left(10, \mathrm{M}^{+}\right), 159$ (53), 117 (100), 90 (9), 79 (9), 43 (5).

exo-1: ${ }^{1} \mathrm{H}$ NMR $\left(300 \mathrm{MHz}, \mathrm{CDCl}_{3}\right)$ : characteristical signals: $\delta 4.3$ and $4.5\left(2 \mathrm{dd}, J_{l}=\right.$ $9.03 \mathrm{~Hz}, 1 \mathrm{H}), 8.2$ and $7.1(\mathrm{~d}, J=8.1 \mathrm{~Hz}, 1 \mathrm{H})$; signals are doubled due to the presence of two amide rotamers. MS: $m / z(\%): 239\left(8, \mathbf{M}^{+}\right), 159$ (55), 117 (100), 90 (9), 79 (9), 43 (5). 

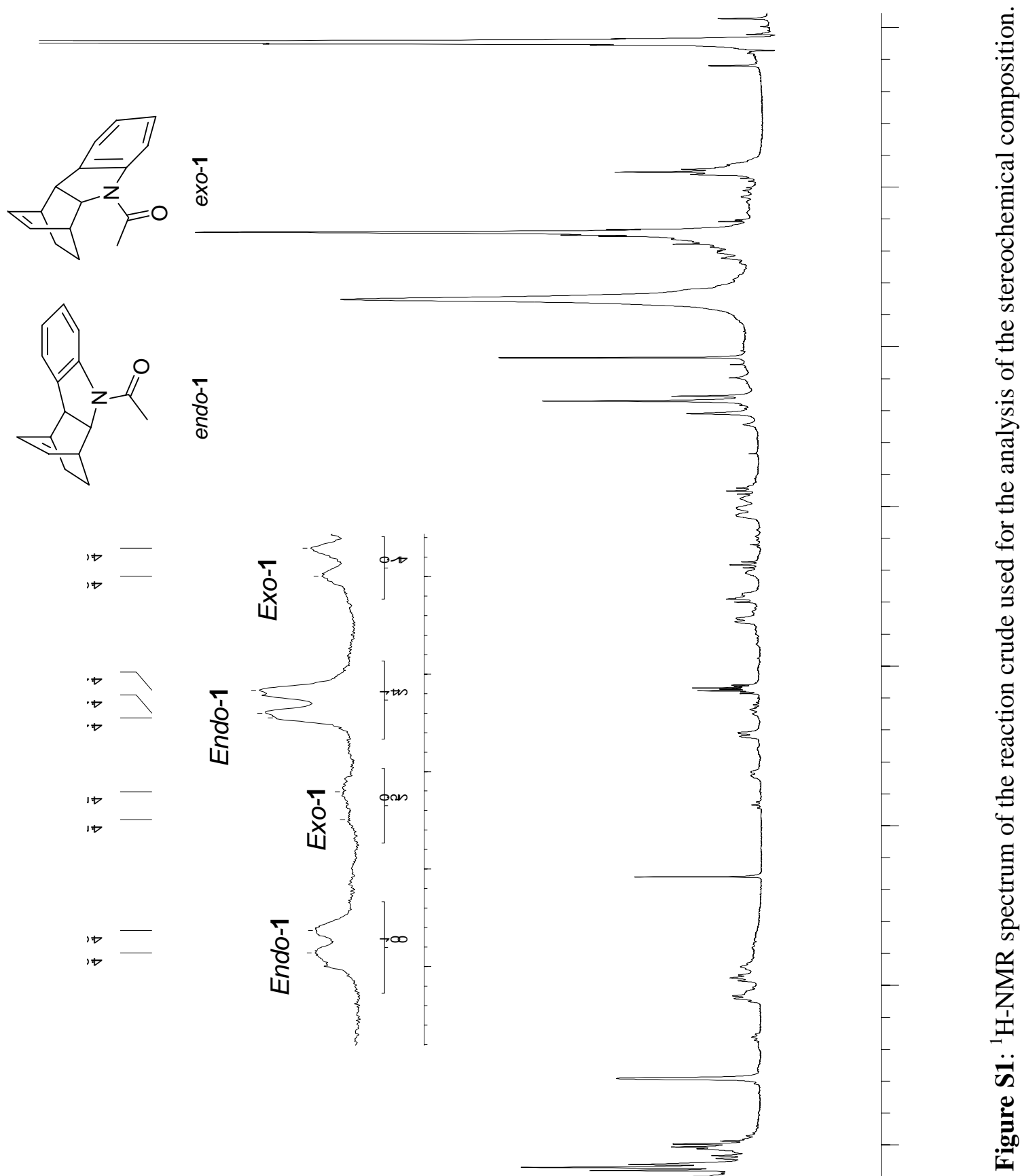

.

10

:<smiles>[C-]CO[CH-]</smiles>

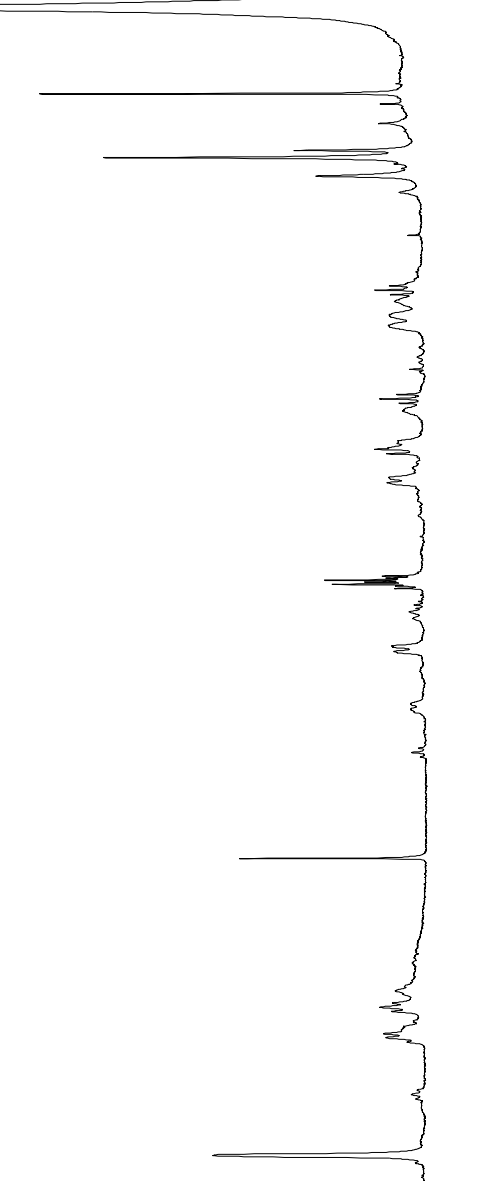




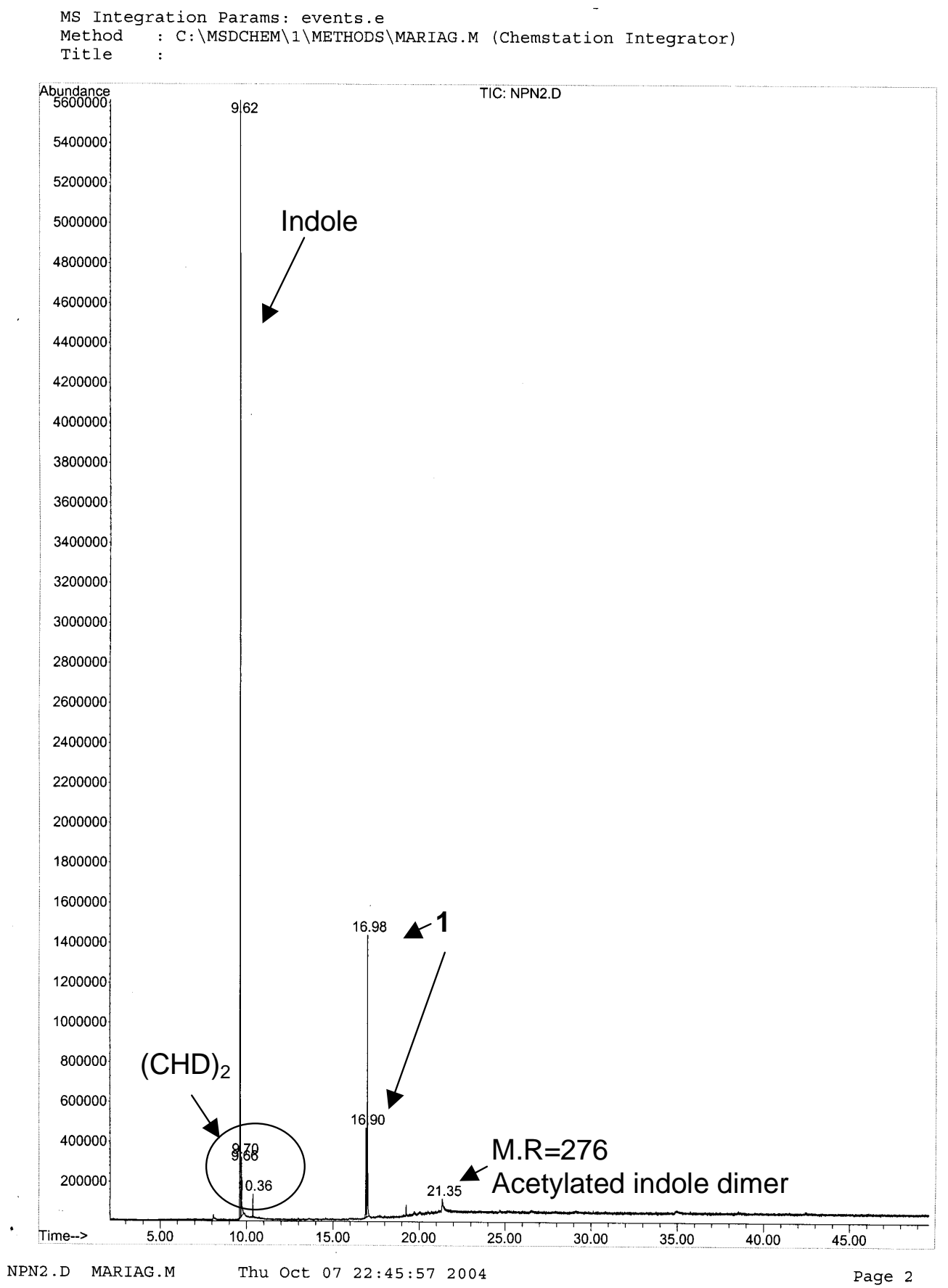

Figure S2: GC trace of the reaction crude. 


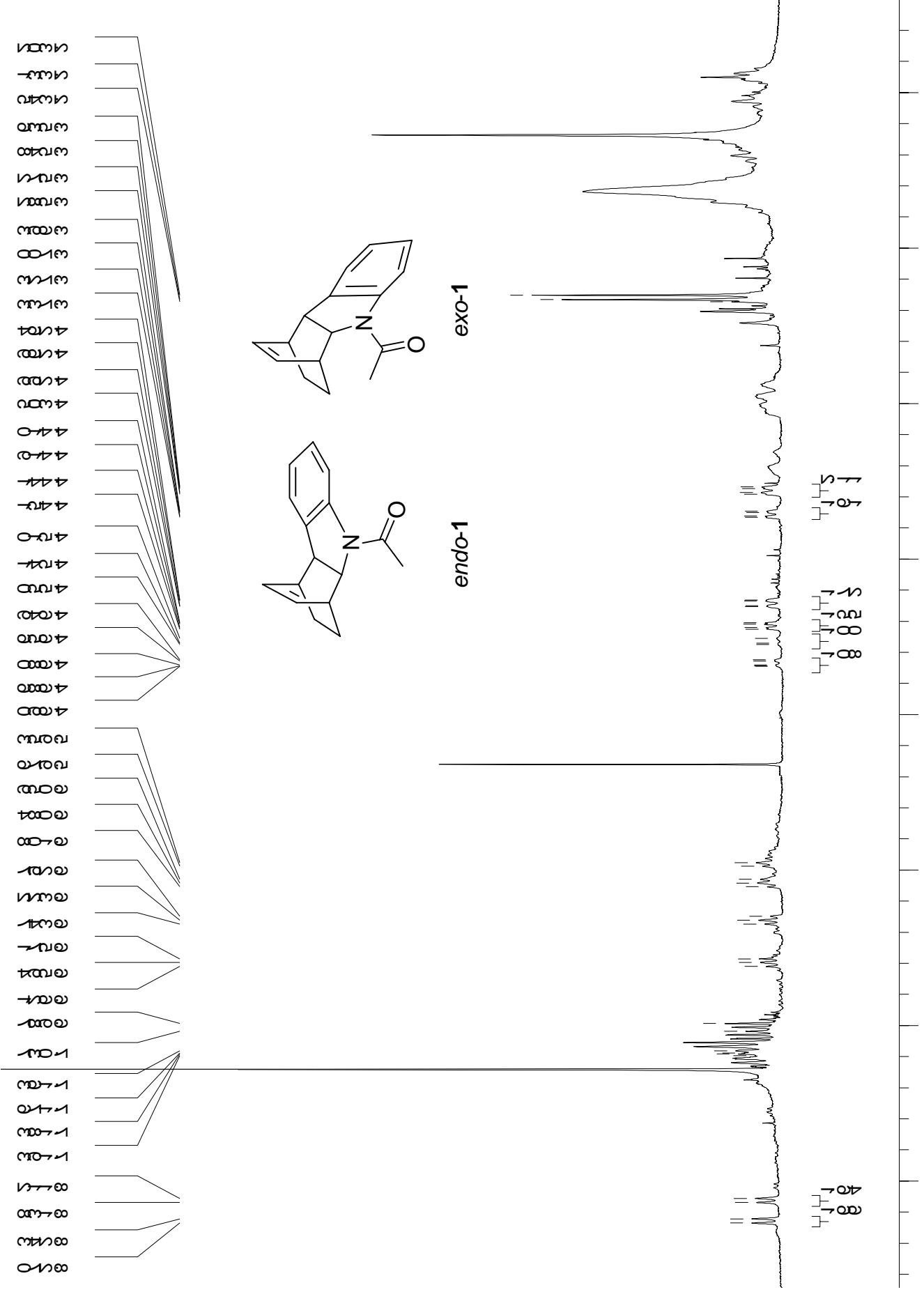




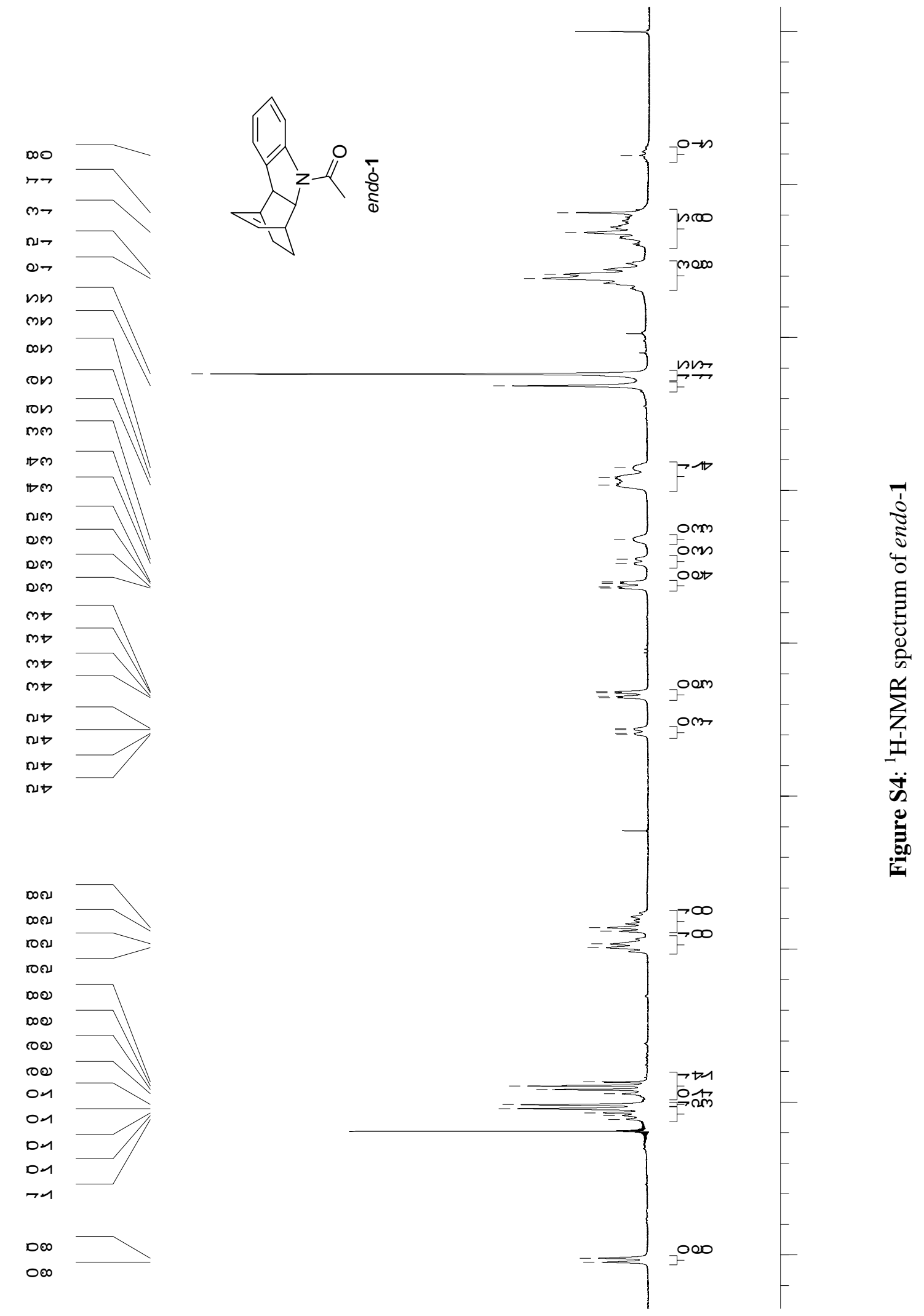



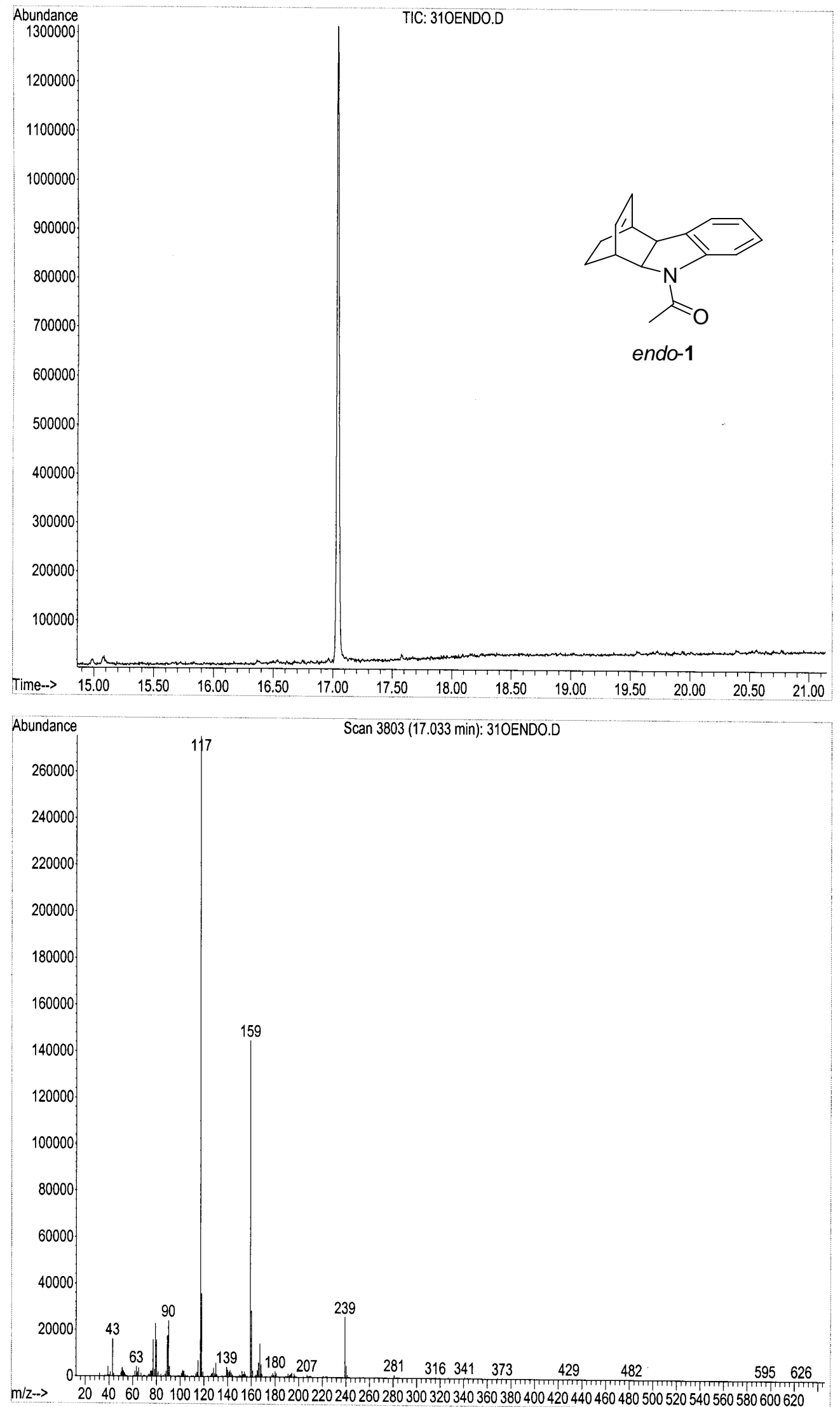

Figure S5: GC/MS spectrum of endo-1. 


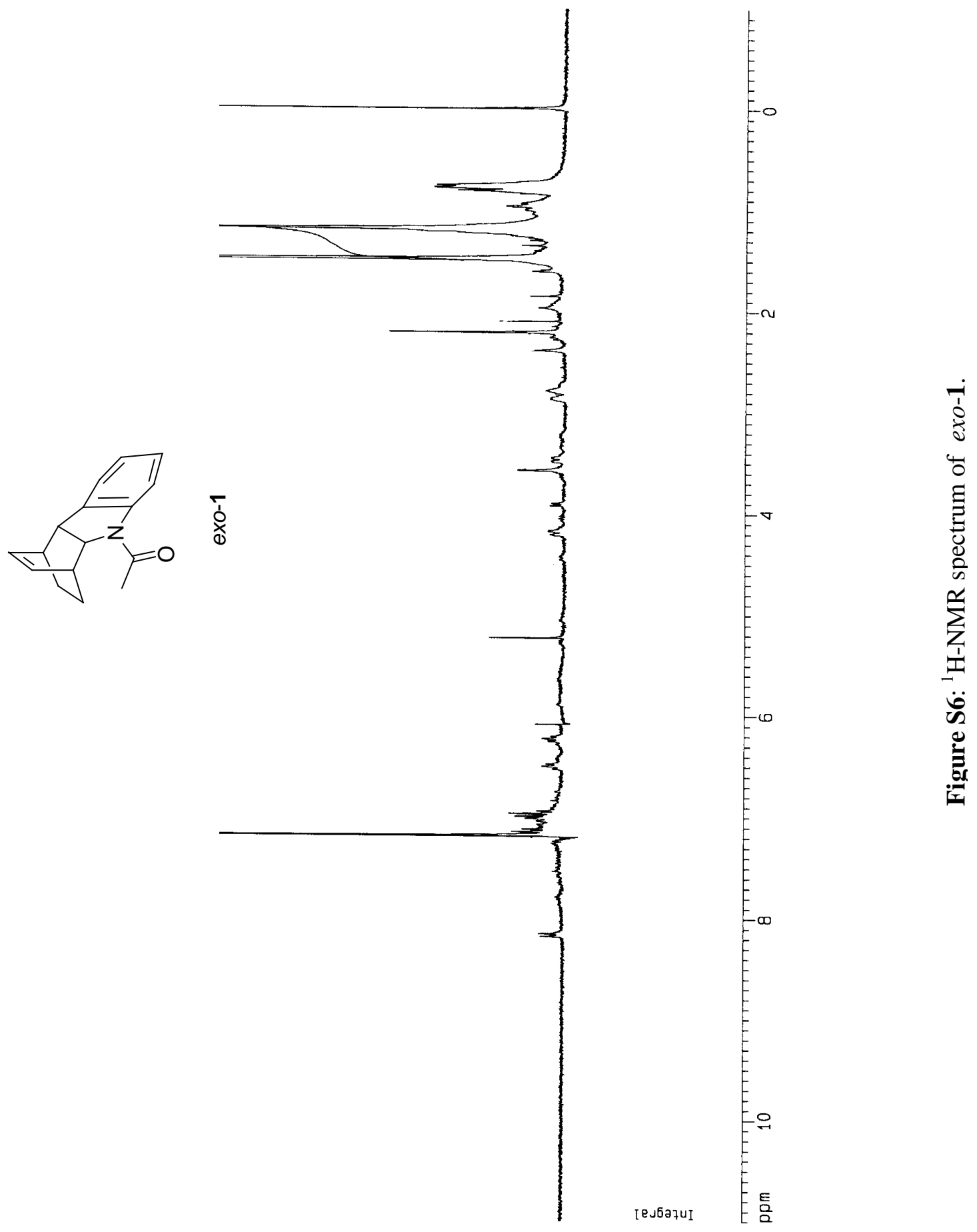



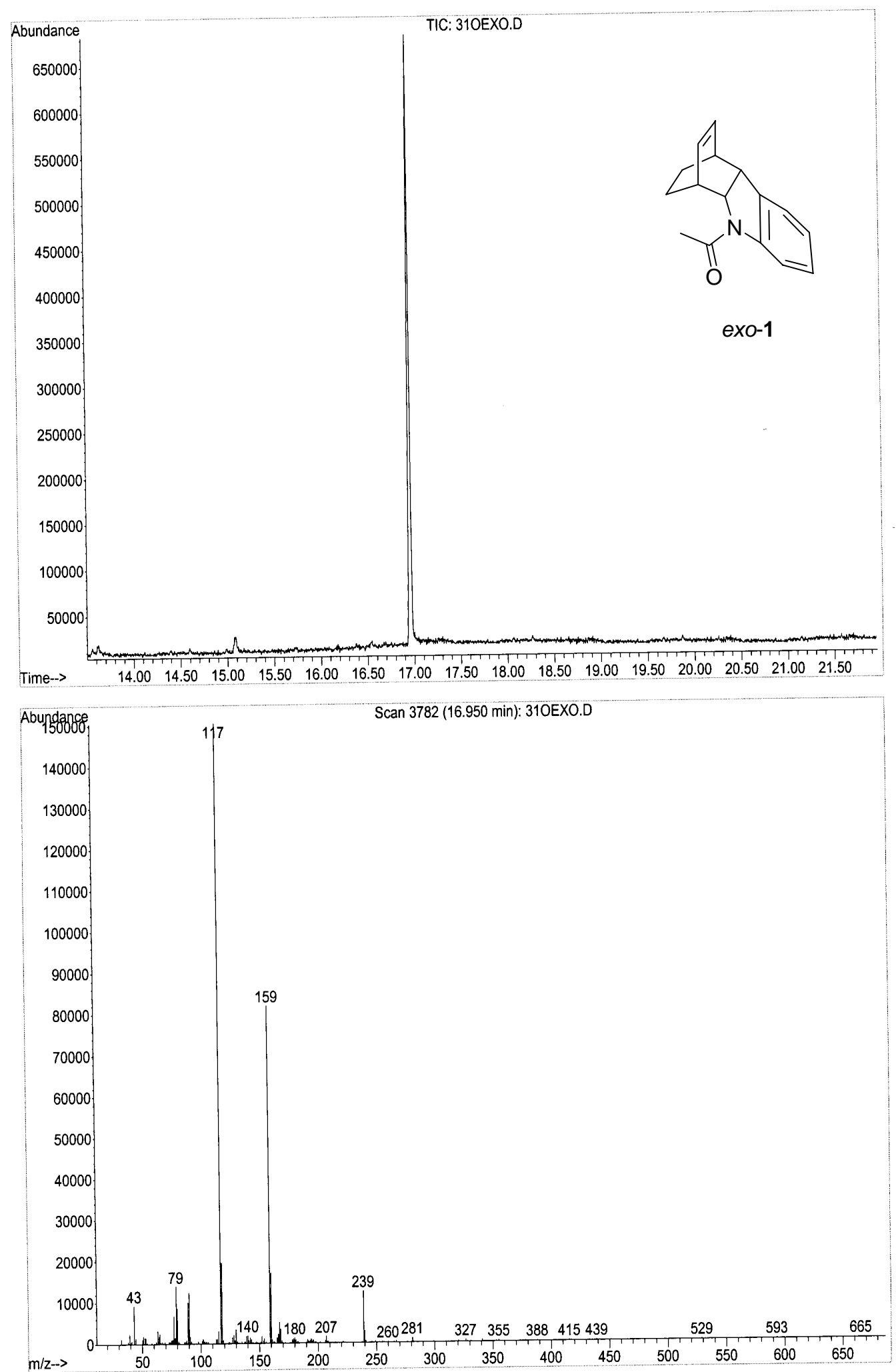

Figure S7: GC/MS spectrum of exo-1 